\section{PEPPERDINE \\ UNIVERSITY}

Journal of the National Association of

Administrative Law Judiciary

$10-15-1990$

\title{
Judicial Deference to Administrative Interpretations of Law
}

Antonin Scalia

Follow this and additional works at: https://digitalcommons.pepperdine.edu/naalj

Part of the Administrative Law Commons, Judges Commons, and the Legal History Commons

\section{Recommended Citation}

Antonin Scalia, Judicial Deference to Administrative Interpretations of Law, 10 J. Nat'I Ass'n Admin. L. Judges. (1990)

available at https://digitalcommons.pepperdine.edu/naalj/vol10/iss2/3

This Speech is brought to you for free and open access by the Caruso School of Law at Pepperdine Digital Commons. It has been accepted for inclusion in Journal of the National Association of Administrative Law Judiciary by an authorized editor of Pepperdine Digital Commons. For more information, please contact bailey.berry@pepperdine.edu. 


\title{
JUDICIAL DEFEREACE TO ADMTHISTPATIVE INTERPRETATIONS OF LAW
}

\author{
The Honorable Antonin Scalia $\underline{2}$
}

When I was invited to speak here at Duke Law school, I had originally intended to give a talk that reflected upon the relationship among the Bork confirmation hearings, the proposed federal salary increase, capital punishment, Roe v. Wade, and Law and Astrology. I was advised, however, that the subject of this lecture series is administrative $l a w$, and so have had to limit myself accordingly. Administrative law is not for sissies--so you should lean back, clutch the sides of your chairs, and steel yourselves for a pretty dull lecture. There will be a quiz afterwards.

Five Terms ago, the supreme Cgyrt issued 1ts opinion in the case of Chevron, U.S.A. Inc. V. NRDC, 3 which announced the principle that the courts will accept an agency's reasonable interpretation of the ambiguous terms of a statute that the agency administers.

Dealing with the question whether the Environmental Protection Agency could permissibly adopt the "bubble concept"-that is, a plantwide definition of "stationary source"--under the clean Air Act, Justice stevens for a unanimous Court adopted an analytical approach that deals with the problem of judicial deference to agency interpretations of law in two steps:

First, always, is the question whether congress has directly spoken to the precise question at issue. If the intent of Congress is clear, that is the end of the matter; for the court, as well as the agency, must giyg effect to the unambiguously expressed intent of Congress.

$1 /$ Duke Law Journal Administrative Law Lecture, delivered at Duke Univeraity School of Law, Jenuary 24, 1989. Copyright (c) 1989 by Antonin scalia. This article was first published in 1989 puke hav Journal 511, and is reprinted here by permission.

2/ Associate Justice, United states supreme Court.

그 467 U.S. $837(1984)$.

4/ Id. at 842-43 (footnote omitted). $11 \overline{8}$ 
Failing an affirmative response to the first inquiry, the Chevron analysis moves to step two:

If, however, the court determines that Congress has not directly addressed the precise question at issue, the court does not simply impose its own construction on the statute, as would be necessary in the absence of an administrative interpretation. Rather, if the statute is silent or ambiguous with respect to the specific issue, the question for the court is whether the agency's ghswer is based on a permissible construction of the statute.

Chevron has proven a highly important decision--perhaps the most important in the field of administrative law since Vermont yankee Nuclear Power Corp. $v$. NRDC. - In the first three and a half years after its announcement--up to the beginning of 1988 --Chevron was cited by lower federal courts over 600 times. 77 Chevron has been a source of lively debate on my own court, centering largely on the question whether it applies with full force (as I believe it does) when the controversy involves a "pure question of statutory construction." $8 /$ In a case in which Justice Kennedy did not participate last Term, thig, question equally divided the eight remaining members of the Court. I Because Justice stevens is not here to reply, it

5/ Id. at 843 (footnotes omitted).

6/ 435 U.S. $519(1978)$.

I/ See Byse, Judicial Review of Administrative Interpretation of Statutes: An Analysis of Chevron's Step Two, 2 Admin. L.J. 255, 255 $(1988)$.

8/ Compare INS V. Cardoza-Eonseca, 480 U.S. 421,446 (1987) (courts may use "traditional tools of statutory construction" to supplant agency's interpretation of congressional intent with judicial interpretation) with id. at 454 (Scalia, J., concurring) ("courts must give effect to a reasonable agency interpretation of a statute unless that interpretation is inconsistent with a clearly expressed congressional intent").

I/ Compaxe NLRB v. United Food \& Commercial Norkers Union, Local 23 , 108 s.Ct. 413, 421 (1988) (advocating that judges determine congressional intent by using "traditional tools of statutory construction") with id, at 426 (Scalia, J., joined by Rehnquist, C.J., \& white \& (Footnote Continued) 
would be unfair of me to address that particular issue, but I do want to explore with you the general theoretical underpinnings of chevron and some of its practical implications.

It should not be thought that the Chevron doctrine--except in the clarity and the seemingly categorical nature of its expression - is entirely new law. To the contrary, courts have been content to accept "reasonable" executive interpretations of law for some time. Consider the following description of judicial review of administrative action, written almost fifty years ago by the Attorney General's Committee on Administrative Procedure, whose Report formed the basis for enactment of our basic charter of administrative law, the Administrative Procedure Act:

Even on questions of law [independent judicial] judgment seems not to be compelled. The question of statutory interpretation might be approached by the court de novo and given the answer which the court thinks to be the "right interpretation." Or the court might approach it, somewhat as a question of fact, to ascertain, not the "right interpretation," but only whether the administrative interpretation has substantial support. Certain standards of interpretation guide in that direction. Thus, where the statute is reasonably susceptible of more than one interpretation, the court may accept that of the administrative body. Again, the administrative interpretation is to be given weight--not merely as the opinion of some men or even of a lower tribunal, but as the opintion of the body especially familiar with the problems dealt with by the statute and burdened with the duty of enforcing it. This may be leglslation deals with ${ }_{1} 89^{m p l e x}$ matters calling for expert knowledge and judgment.

That was written, as I say, almost half a century ago, and was an accurate description of the caselaw. Judge Henry Friendly observed the same landscape thirty years later, when he wrote:

We think it is time to recognize. . . that there are two lines of Supreme court decisions on this subject which are analytically in conflict, with the result that a court of appeals must choose the one it deems more appropriate for the case at hand. Leading cases support [] the view that great deference must be given to

(Eootnote Continued)

O'Connor, JJ., concurring) (courts should determine whether an agency's interpretation of a statute is permissible, not correct). 120

10/ S. Doc. No. 8, 77th Cong., 1st Sess. 90-91 (1941). 
the decisions of an administrative agency applying a statute to the facts and that such decisions can be reversed only if without rational basis... However, there is an impressive body of law sanctioning free substitution of judicial for administrative judgmept, when the question involves the meaning of a statutory term.

Chevron, if its categorical language is to be believed, and if the Court intends to stand by it, essentially chose between these two conflicting lines of decision.

It is not immediately apparent why a court should ever accept the judgment of an executive agency on a question of law. Indeed, on its face the suggestion seems quite incompatible with Marshall's aphorism that "[i]t is emphatically the province and duty of the judicial department to say what the law is." 12 surely the law, that immutable product of Congress, is what it is, and its content--ultimately to be decided by the courts--cannot be altered or affected by what the Executive thinks about it. I suppose it is harmless enough to speak about "giving deference to the views of the Executive" concerning the meaning of a statute, just as we speak of "giving deference to the views of the Congress" concerning the constitutionality of particular legislation--the mealymouthed word "deference" not necessarily meaning anything more than considering those views with attentiveness and profound respect, before we reject them. But to say that those views, if at least reasonable, will ever be binding--that is, seemingly, a striking abdication of judicial responsibility.

This deep-rooted feeling that it is the judges who must say what the law is accounts, I have no doubt, for the stubborn refusal of lawyers, and even of Congress, to admit that courts ever accept executive interpretation. For example, despite the Attorney General's Committee's description of current law that $I$ quoted earlier, one provision of the Administrative Procedure Act (APA) itself seems to have been based upon the quite mistaken assumption that questions of law would always be decided de novo by the courts. You may have wondered why the APA's required notice-and-comment procedures for rulemaking--probably the most significant innovation of the legislation -contain an exception for "interpretive rules." One of the reasons

11/ Pittston stevedoring Corp. V. Dellaventura, 544 F.2d 35, 49 (2d Cir. 1976), aff'd sub nom. Northeast Marine Terminal Co. v. Caputo.

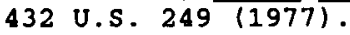

12/ Marbury y. Madison, 5 U.S. (1 Cranch) 137,177 (1803). 
given in the 1945 senate Print is as follows: "'[I]nterpretative' rules--as merely interpretations of ptgtutory provisions--are subject to plenary judicial review . . . ." 13 That is not true today, and it was not categorically true in 1945.

What, then, is the theoretical justification for allowing reasonable administrative interpretations to govern? The cases, old and new, that accept administrative interpretations, of ten refer to the "expertise" of the agencies in question, their intense familiarity with the history and purposes of the legislation at issue, their practical knowledge of what will best effectuate those purposes. In other words, they are more likely than the courts to reach the correct result. That is, if true, a good practical reason for accepting the agency's views, but hardly a valid theoretical justification for doing so. If I had been sitting on the supreme Court when Learned Hand was still alive, it would similarly have been, as a practical matter, desirable for me to accept his views in all of his cases under review, on the basis that he is a lot wiser than $I$, and more likely to get it right. But that would hardly have been theoretically valid. Even if Hand would have been de facto superior, I would have been ex officio so. So also with judicial acceptance of the agencies' views. If it is, as we have always believed, the constitutional duty of the courts to say what the law is, we must search for something beyond relative competence as a basis for ignoring that principle when agency action is at issue.

One possible validating rationale that has been suggested in some recent articles $1 \mathrm{~d}$--and that can perpaps even be derived from some of the language of Chevron itself 15 --is that the constitutional principle of separation of powers requires chevron. The argument goes something like this: When, in a statute to be implemented by an executive agency. Congress leaves an ambiguity that cannot be resolved by text or legislative history, the "traditional tools of statutory construction," the resolution of that ambiguity

13/ s. Doc. No. 248, 79th Cong., 2d Sess. 18 (1946).

14/ See Rmiec, Judicial Deference to Executive Agencies and the Decline of the Nondeleration Doctrine, 2 Admin. L.J. 269, 277-78, 283, 285 (1988); Cf. Starx, Judicial Review in the Post-Chevron Bra, 3 Yale J. on Reg. $283,308,312(1986)$ (Chevron shifts policy-making responsibility from courts to "democratically accountable officials" in agencies).

15/ See Chevron, U.S.A., Inc, V, NRDC, 467 U.S. 837, 864-66 (1984). 122 
necessarily involves policy judgment. Under our democratic system, policy judgments are not for the courts but for the political branches; Congress having left the policy question open, it must be answered by the Executive.

Now there is no one more fond of our system of separation of powers than I am, but even I cannot agree with this approach. To begin with, it seems to me that the "traditional tools of statutory construction" include not merely text and legislative history but also, quite specifically, the consideration of policy consequences. Indeed, that tool is so traditional that it has been enshrined in Latin: "Ratio est leqis anima; mutata leqis ratione mutatur et lex." ("The reason for the law is its soul; when the reason for the law changes, the law changes as well.") Surely one of the most frequent justifications courts give for choosing a particular construction is that the alternative interpretation would produce "absurd" results, or results less compatible with the reason or purpose of the statute. This, it seems to me, unquestionably involves judicial consideration and evaluation of competing policies, and for precisely the same purpose for which (in the context we are discussing here) agencles consider and evaluate them--to determine which one will best effectuate the statutory purpose. Policy evaluation is, in other pords, part of the traditional judicial tool-kit that is used in applying the first step of Chevron--the step that determines, before deferring to agency judgment, whether the law is indeed ambiguous. Only when the court concludes that the policy furthered by neither textually possible interpretation will be clearly "better" (in the sense of achieving what Congress apparently wished to achieve) will it, pursuant to Chevron, yield to the agency's choice. But the reason it yields is assurediy not that it has no constitutional competence to consider and evaluate policy.

The separation-of-powers justification can be rejected even more painlessly by asking one simple question: If, in the statute at issue in Chevron. Congress had specified that in all suits involving interpretation or application of the clean Air Act the courts were to give no deference to the agency's views, but were to determine the issue de novo, would the supreme Court nonetheless have acquiesced in the agency's views? I think the answer is clearly no, which means that it is not any constitutional impediment to "policy-making" that explains Chevron.

In my view, the theoretical justification for chevron is no different from the theoretical justification for those pre-chevron cases that sometimes deferred to agency legal determinations. As the D.C. Circuit, quoting the First circuit, expressed it: "The extent to which courts should defer to agency interpretations of law is ultimately 'a function of Congress' intent on the subject as revealed 
in the particular statutory scheme at issue." " $\underline{16 /}$ An ambiguity in a statute committed to agency implementation can be attributed to either of two congressional desires: (1) Congress intended a particular result, but was not clear about it; or (2) Congress had no particular intent on the subject, but meant to leave its resolution to the agency. When the former is the case, what we have is genuinely a question of law, properly to be resolved by the courts. When the latter is the case, what we have is the conferral of discretion upon the agency, and the only question of law presented to the courts is whether the agency has acted within the scope of its discretion--i.e., whether its resolution of the ambiguity is reasonable. As I read the history of developments in this field, the pre-Chevron decisions sought to choose between $(1)$ and $(2)$ on a statute-by-statute basis. Hence the relevance of such frequently mentioned factors as the degree of the agency's expertise, the complexity of the question at 1ssue, and the existence of rulemaking authority within the agency. All these factors make an intent to confer discretion upon the agency more likely. Chevron, however, if it is to be belleved, replaced this statute-by-statute evaluation (which was assuredly a font of uncertainty and litigation) with an across-the-board presumption that, in the case of ambiguity, agency discretion is meant.

It is beyond the scope of these remarks to defend that presumption (I was not on the Court, after all, when Chevron was decided). Surely, however, it is a more rational presumption today than it would have been thirty years ago--which explains the change in the law. Broad delegation to the Executive is the hallmark of the modern administrative state; agency rulemaking powers are the rule rather than, as they once were, the exception; and as the sheer number of modern departments and agencies suggests, we are awash in agency "expertise." If the chevron rule is not a $100 \%$ accurate estimation of modern congressional intent, the prior case-by-case evaluation was not so either--and was becoming less and less so, as the sheer volume of modern dockets made it less and less possible for the supreme court to police diverse application of an ineffable rule. And to tell the truth, the quest for the "genuine" legislative intent is probably a wild-goose chase anyway. In the vast majority of cases I expect that Congress neither (1) intended a single result, nor

16/ Process Gas Consumers Group $v$. United States Dep't of Agric..' 694 F.2d 778, 791 (D.C. Cir. 1982) (en banc) (quoting constance v. Secretaxy of Health Human Servs, 672 F.2d 990, 995 (1st Cir. 1982)), cert. denied, 461 U.S. 905 (1983); see also Ford Motor Credit Co. v. Milhollin, 444 U.S. 555, 566-68 (1980) (Truth in Lending Act requires judicial deference to rational lawmaking by Federal Reserve Bgard). 
(2) meant to confer discretion upon the agency, but rather (3) didn't think about the matter at all. If $I$ am correct in that, then any rule adopted in this field represents merely a fictional, presumed intent, and operates principally as a background rule of law against which Congress can legislate.

If that is the principal function to be served, Chevron is unquestionably better than what preceded it. Congress now knows that the ambiguities it creates, whether intentionally or unintentionally, will be resolved, within the bounds of permissible interpretation, not by the courts but by a particular agency, whose policy biases will ordinarily be known. The legislative process becomes less of a sporting event when those supporting and opposing a particular disposition do not have to gamble upon whether, if they say nothing about it in the statute, the ultimate answer will be provided by the courts or rather by the Department of Labor.

The theory that judicial acquiescence in reasonable agency determinations of law rests upon real or presumed legislative intent to confer discretion has certain consequences which the courts do not yet seem to have grasped. For one thing, there is no longer any justification for giving "special" deference to "long-standing and consistent" agency interpretations of law. That venerable principle made a lot of sense when we assumed that both court and agency were searching for the one, permanent, "correct" meaning of the statute: it makes no sense when we acknowledge that the agency is free to give the statute whichever of several possible meanings it thinks most conducive to accomplishment of the statutory purpose. Under the latter regime, there is no apparent justification for holding the agency to its first answer, or penalizing it for a change of mind.

Indeed, it seems to me that such an approach would deprive Chevron of one of its major advantages from the standpoint of governmental theory, which is to permit needed flexibility, and appropriate political participation, in the administrative process. One of the major disadvantages of having the courts resolve ambiguities is that they resolve them for ever and ever; only statutory amendment can produce a change. If the word "stationary source" in the clean Air Act did not permit the "bubble concept" today, it would not permit the "bubble concept" four years from now either, no matter how much the perception of whether that concept impairs or furthers the objectives of the Act may change. Under Chevron, however, "stationary source" can mean a range of things, and it is up to the agency, in light of its advancing knowledge (and also, to be realistic about it, in light of the changing political pressures that it feels from Congress and from its various constituencies) to specify the correct meaning. If Congress is to delegate broadly, as modern times are thought to demand, it seems to me desirable that the delegee be able to suit its actions to the times, and that continuing political 
accountability be assured, through direct political pressures upon the Bxecutive and through the indirect political pressure of congressional oversight. All this is lost if "new" or "changing" agency interpretations are somehow suspect. There are of course well established restrictions upon sudden 199 irrational changes of interpretation through adjudication. 17 and statutorily prescribed procedures (including a requirement of reasoned justification) for changes of interpretation through rulemaking. 18 and at some point, I suppose, repeated changes back and forth may rise (or descend) to the level of "arbitrary and capricious," and thus unlawful, agency action. But so long as these limitations are complied with, there seems to me no reason to value a new interpretation less than an old one. (I should also add that the existence of a "long-standing, consistent agency interpretation" that dates to the original enactment of the statute may be relevant to the first step of Chovron--that is, it may be part of the evidence showing that the statute is in fact not ambiguous but has a clearly defined meaning.)

Let me digress for a moment here, to note that the capacity of the Chevron approach to accept changes in agency interpretation ungrudaingly seems to me one of the strongest indications that the chevron approach is correct. It has always seemed to me utterly unrealistic to believe that when an agency revises one of its interpretative regulations, or one of the legal rules that it applies in its adjudications--when the NLRB, for example, decides that employer action previously held to be an "unfair labor practice" is no longer so, or when the Federal Trade Commission amends one of its regulations to declare action previously permitted an "unfair or deceptive trade practice"-the agency was admitting that it had "got the law wrong." And it has thus seemed to me inappropriate to look askance at such changes, as though we were dealing with a judge who cannot make up his mind whether the rule in shelley's Case applies or not. Rather, the agency was simply "changing the law," in light of new information or even new social attitudes impressed upon it through the political process--all within the limited range of discretion to "change the law" conferred by the governing statute. Chevron, as I say, permits recognition of this reality.

17 See $4 \mathrm{R}$. Davis, Administrative Lap Treatise Section 20.11, at 38-39 (2d ed. 1983).

18/ See Motor Vehicle Mfrs. Ass'n v, State Farm Mut. Auto. Ins. Co., 463 U.S. 29,57 (1983). 
Perhaps another distinction of yesteryear that must, in light of Chevron, be revised, is the distinction among the various manners in which the agency makes its legal views known: scholarly perceptions on that point have evolved considerably over the years. Dean Landis, for example, wrote in 1938 that deference was owed to agency interpretation of law adopted in rulemaking but not in adjudication--because the authority to make rules implied congressional delegation of discretion, whereas authority to adjudicate did not. 19 / A more enduring distinction has been that which denies deference to agency interpretations of law "adopted for the purpose of litigation." Certainly that makes sense under a regime in which the agency interpretation is accepted only because the "expert" agency is more likely than the court to reach the single "right" legal answer. A position formulated not in the agency's adjudication process, nor in rulemaking, but in a brief to a court, does not seem like the last stage of an "expert" search for the truth. Once it is accepted, however, that there are various "right" answers, and that policy and indeed even political considerations (in the nonpartisan sense) can legitimately affect which one the agency may choose, then it seems less important whether the choice is made through rulemaking and adjudication, or rather through a formal presentation of the agency's position in court. of course in many situations the agency position can only lawfully be adopted through specified procedures; a litigating position cannot repeal an extant regulation. And in many situations there may be reason to doubt whether the position taken by a low-level agency litigator, or perhaps even by the general counsel, has the approval of the agency head. And of course legal positions taken (in litigation or otherwisel with respect to matters that are not committed to the agency's administration do not qualify for Chevron treatment anyway. But if the matter at issue is one for which the agency has responsibility, if all requisite procedures have been complied with, and if there is no doubt that the position urged has full and considered approval of the agency head, it is far from self-evident that the agency's views should be denied their accustomed force simply because they are first presented in the prosecution of a lawsuit.

The view on the other side is that even if "expertness" is no longer as revered as it used to be, impartiality is. Whatever else an agency's choice among the various interpretive options may be based upon, it should not be based upon the desire to win a particular

19/ J. Landis, The Administrative Process 147-49 (1938).

$20 /$ Cf. INS. v. Cardozo-Fonseca, 480 U.S. $421,446-50 \& \mathrm{n} .30$ (1987) (contrasting Board of Immigration Appeals decisions and the government's litigation position). 
1awsuit. To avoid the risk of this, the assumed delegation of "law-making" discretion upon which Chevron rests should be deemed applicable only to agency determinations made (with sufficient formality) in the regular course of the agency's business, and not in litigation. Essentially this point of view is taken by a recent consultapf;s report to the Administrative Conference of the United states. 1 I would say that the jury ifs still out on this; one can foresee future disputes on the point.

There is one final point I wish to discuss: What does it take to satisfy the first step of Chevron--that is, when is a statute ambiguous? Chevron becomes virtually meaningless, it seems to me, if ambiguity exists only when the arguments for and against the various possible interpretations are in absolute equipoise. If nature knows of such equipoise in legal arguments, the courts at least do not. The judicial task, every day, consists of finding the right answer, no matter how closely balanced the question may seem to be. In appellate optnions, there is no such thing as a tie. If the judicial mentality that is developed by such a system were set to answering the question, "When are the arguments for and against a particular statutory interpretation in equipoise?," I am certain that the response would be "almost never." If Chevron is to have any meaning. then, congressional intent must be regarded as "ambiguous" not just when no interpretation is even marginally better than any other, but rather when two or more reasonable, though not necessarily equaily valid, interpretations exist. This is indeed intimated by the opinion in Chevron--which suggests that the opposite of "ambiguity"

21/ See R. Anthony, Which Agency Interpretations Should Bind the Courta? 71-76, 101-03 (November 1988) (Report to the Administrative Conference of the United States).

22/ Compare Church of Scientology v. IRS, 792 F.2d 153, 162 n.4 (D.C. CAr. 1986) (en banc) ("There is some question. . . whether an interpretive theory put forth only by agency counsel in iitigation, which explains agency action that could be explained on different theories, constitutes an 'agency position' for purposes of Chevron."), aff'd, 484 U.S. 9 (1987) with 1d. at 165 (Silbermann, J., concurring) ("We know that the IRS has been advancing its interpretation in courts throughout the country at least since 1982 . . . . To suggest in these circumstances that [this] is not an 'agency position' is to Imply that IRS counsel are mavericks, disembodied from the agency that they represent. I reject that supposition.") 
is not "resolvability" but rather "clarity." $\underline{23}$ / Here, of course, is the chink in Chevron's armor--the ambiguity that prevents it from being an absolutely clear guide to future judicial decisions (though still a better one than what it supplanted). How clear is clear? It is here. If Chevron is not abandoned, that the future battles over acceptance of agency interpretations of law will be fought. Some indications of that can already be found in Supreme Court opinions.

I cannot resist the temptation to tie this lecture into an impenetrable whole, by observing that where one stands on this last point--how clear is clear--may have much to do with where one stands on the earlier points of what Chevron means and whether Chevron is desirable. In my experience, there is a fairly close correlation between the degree to which a person is (for want of a better word) a "strict constructionist" of statutes, and the degree to which that person favors Chevron and is willing to give it broad scope. The reason is obvious. One who finds more of ten (as I do) that the meaning of a statute is apparent from its text and from its relationship with other laws, thereby finds less often that the triggering requirement for Chevron deference exists. It is thus relatively rare that Chevron will require me to accept an interpretation which, though reasonable, I would not personally adopt. Contrariwise, one who abhors a "plain meaning" rule, and is willing to permit the apparent meaning of a statute to be impeached by the legislative history, will more frequently find agency-liberating ambiguity, and will discern a much broader range of "reasonable" interpretation that the agency may adopt and to which the courts must pay deference. The Erequency with which Chevron will require that judge to accept an interpretation he thinks wrong is infinitely greater.

The law does not move in a straight line, and $I$ will be surprised if the implications of Chevron that I have discussed--and others that I have not mentioned--are immediately grasped and applied by the federal courts. The opinions we federal judges read, and the cases we cite, are full of references to the old criteria of "agency expertise," "the technical and complex nature of the question presented," "the consistent and longstanding agency position"--and it will take some time to understand that those concepts are no longer relevant, or no longer relevant in the same way. Indeed, it may be

23/ See Chevron, U.S.A. Inc. V. NRDC, 467 U.S. 837,842 (1984) ("If the intent of Congress is clear, that is the end of the matter . . .") (emphasis added); see also Chemical Mfrs. Ass'n v. NRDC. 470 U.S. 116, 125 (1985) ("Of course, if Congress has clearly expressed an intent contrary to that of the Agency, our duty is to enforce the will of Congress.") (emphasis added). 
that, for a time at least, fidelity to the old formulations will unnaturally constrict Chevron, or even produce a retreat from its basic perception. I tend to think, however, that in the long run Chevron will endure and be given its full scope--not so much because it represents a rule that is easier to follow and thus easier to predict (though that is true enough), but because it more accurately reflects the reality of government, and thus more adequately serves its needs. 